\title{
Becoming a Teacher Educator: Evidence from the Field
}

\author{
by
}

\author{
Jean Murray and Trevor Male
}

[Published in: Teaching and Teacher Education, February 2005, 21 (2),125-142]

\begin{abstract}
This article makes a contribution to understanding the challenges new teacher educators face in establishing their professional identities in Higher Education. The data collected for the study allowed the researchers to analyse the tensions and conflicts arising for 28 teacher educators in their first 3 years of working on Initial Teacher Education (ITE) courses in England. The findings of the study show that, despite having previous successful careers in school teaching, the majority of the interviewees took between 2 and 3 years to establish their new professional identities. They faced challenges in two key areas-developing a pedagogy for HE-based ITE work and becoming research active. Meeting both of these challenges required significant adaptations to their previous identities as schoolteachers.
\end{abstract}

\section{Introduction}

Despite the wealth of commentaries on teacher education there is little empirical research focused on teacher educators themselves (see Maguire, 1994; Grundy \& Hatton, 1995; John, 1996; Korthagen, 2000). In particular, few studies look at teacher educators' professional experiences and induction needs as they enter Higher Education (HE) institutions to take on academic roles. This omission means that new teacher educators are an under-researched and poorly understood occupational group (Murray, 2003).

This article makes a contribution to understanding the challenges new teacher educators face in establishing their professional identities as teachers of teachers and as scholars in HE. In particular, the data collected for the study allowed the researchers to analyse the tensions and conflicts arising for 28 teacher educators in their first 3 years of working on Initial Teacher Education (ITE) courses in England. The findings of the study show that, despite having previous successful careers in school teaching, the majority of the interviewees took between 2 and 3 years to establish their new professional identities. They faced challenges in two key areas developing a pedagogy for HE-based ITE work and becoming research active. Meeting both of these challenges required significant adaptations to their previous 
identities as schoolteachers. The transition required the development of a new body of knowledge, skills and expertise that, in part, drew on previous knowledge and experience as a schoolteacher.

\section{Teacher Education in England}

In England teacher educators working on ITE courses are certified school teachers, typically with a significant career record of successful practice in primary schools (for pupils aged from 5 to 11 years) or secondary schools (for pupils aged from 11 to 18 years), who have joined an institute of Higher Education 1 to work full-time with student teachers. There are no nationally stated standards for teacher educators' professional knowledge in England, as there are in the Netherlands (see Koster \& Dengerink, 2001) and in the USA (see ATE, 2002), but the general expectations are that all English teacher educators will be effective teachers and facilitators of learning for intending teachers, taking responsibility for induction into the profession. Teacher educators are also expected to further the knowledge base of their specialist field through scholarly activities. This is particularly true for those working in University Departments of Education (UDEs), where there is often the explicit requirement that they will also be active researchers, publishing their work in relevant academic or professional journals and books.

Teacher educators are conceptualised here as moving from being first-order practitioners-that is school teachers-to being second-order practitioners ( Murray, 2002). Where they once worked in the first-order setting of the school, they now work in the second-order setting of HE. For those working mainly as initial teacher educators their academic 'discipline' is their knowledge of schooling, of the first-order context. They enter HE with their experiential knowledge and understanding of school teaching as a major strength. Since this knowledge base has been generated in large part through professional practice, it is often tacit rather than explicit, and is inevitably permeated by that practice and by individual ways of understanding the processes of teaching and learning. These ways of understanding in turn are saturated by personal values, beliefs and biographies. As second-order practitioners teacher educators induct their students into the practices and discourses of both school teaching and teacher education. Watson (2000) outlines a two-part model of academic professionalism for the knowledge and expertise required for all teaching in HE. The 
model consists of firstly, knowledge and expertise in the subject or discipline being taught, and secondly, the pedagogical capability to teach their subject in the HE setting. For teacher educators this model is over-simplistic, however, because the separation of the two elements of expertise, which it implies, is artificial. Knowledge of the 'discipline' or 'subject' of education and the pedagogical knowledge of how to teach that 'subject' in HE are inseparable for teacher educators. For them, teaching and learning are the essential focuses of work in both the first- and second-order settings.

\section{The Transition from School to Teacher Education}

Teacher educators undergo a mid-career transition, leaving their schools to work in $\mathrm{HE}$, to take on academic roles, which differ from the school teaching posts for which they originally trained and in which they have gained expertise. This is a transition that entails the learning of new social mores as a teacher educator and the creation of a new professional identity. In examining the formation of professional identity, Southworth (1995) distinguishes between situational self and substantial self when describing occupational transition. Drawing on the work of Nias (1989), Southworth concluded that situational selves are developed from interaction with others whilst the substantial self is a core of self-defining beliefs relatively impervious to change, many of which are formed through general life experiences. This does not deny the potential for the substantial self to be affected by changes in life experiences, however, and being reframed in accord with altered circumstances. In this study we consider the career transition to a different occupation to be complete when the two aspects of self are closely aligned, even if that entails changes to substantial self. At this point the new entrant feels confident and competent in his/her job, thus experiencing feelings of ease and effectiveness with regards to the demands of the position. Studies of other occupations in education show that, typically, this process is complete within 3 years of appointment (for example Parkay \& Hall, 1992; Day \& Bakioglu, 1996; Reeves, Moos, \& Forrest, 1998; Weindling, 2000).

The few available studies of new teacher educators in various national contexts have identified that the transition between school teaching and work as a teacher educator is often stressful, with many teacher educators having difficulties in adjusting to the expectations of HE (Acker \& Feuerverger, 1997; Ducharme, 1993; Sinkinson, 1997; Hatt, 1997; Nicol, 1997; Murray, 2003). Uncertainty about new professional roles 
(Wilson, 1990), the difficulty of adjusting to the pedagogical skills needed to work with adult learners (Kremer-Hayon \& Zuzovsky, 1995; Department of Education and Science, 1987) and concerns about the adequacy of the professional and academic knowledge bases necessary for HE work are all identified as areas of stress (KremerHayon \& Zuzovsky, 1995). Ducharme (1993), in common with a number of other analysts (see, for example Lanier \& Little, 1986; Ducharme \& Agne, 1989; Hatton, 1997), identifies sub-groups of teacher educators who continue to adhere to models of teacher educator professionalism in which professional credibility centres on their identities as ex-school teachers, attitudes to research are ambivalent or negative, and the predominant senses of responsibility and commitment are to the school sector. Such teacher educators are seen as limited and as never adjusting to the norms of the HE sector. Such analyses have been defined as creating a 'deficit model' for these teacher educators in which they are seen as at best only semi-academics ( Murray, 2002, p. 77).

The process of adjustment to a new occupation is frequently described through socialisation theory, with observers and researchers identifying professional socialisation (see for example: Daresh, 1995; Barnett, 2001) as the process where the new member learns what it means to be a part of that profession and organisational socialisation as the process by which one learns the knowledge, values, and behaviours required to perform a specific role within a particular organisation ( Schein, 1988). Much of the discourse on organisational socialisation has focused on the issues relating to a single organisation rather than to a system, however, and whilst some issues relating to organisational socialisation will undoubtedly be relevant to the experience of teacher educators in this study, the major focuses of this paper are the adaptations required in achieving the new occupational identity and the overall processes of professional socialisation. In other words, our major concern here is to explore generic issues about what it means to become a teacher educator in English $\mathrm{HE}$, rather than to identify the specific details of what it means to become a teacher educator in a particular HE institution, and the discussion that follows will be framed according to that principle.

New members of a profession usually begin to learn the demands of the job prior to commencement. This has been described as a process of anticipatory socialisation ( 
Taylor, 1968, p. 147; Greenfield, 1985, p. 100; Eraut, 1994, p. 31) whereby prospective post holders prepare themselves through gathering social and technical experiences that will qualify them for the job. Most discussion of anticipatory socialisation is posited on the notion that this is a deliberate process by upwardly mobile aspirants, but Merton draws attention to this process having the propensity to be both conscious and unconscious. In his discussion of anticipatory socialisation, he states:

Conducing to this stage of anticipatory socialization is the structural circumstances of what can be called role gradations. The individual moves more or less continuously through a sequence of statuses and associated roles, each of which does not differ greatly from the one which has gone before. (Merton, 1968, p. 239)

Greenfield interprets Merton as suggesting that these gradations may serve as informal antecedent preparation that is unnoticed by the individual performer. In short, it may be an unconscious process that brings the individual to a position where there is a high likelihood of acquiring some of the values and orientations associated with new, but related roles and statuses (Greenfield, 1977).

Teacher educators in England tend to have limited experience with their new role before entering HE. As schoolteachers, who have experienced ITE themselves at the beginning of their careers, they tend to have ingrained memories and attitudes to the professional induction experience. Later in their school teaching careers they may also have acquired experience of teacher education through being a mentor to ITE students on school experience (teaching practice). Significantly, however, this experience of mentoring happens within a school setting and is often focused on the mentor supporting the student teacher in acquiring the context specific knowledge of how to teach a particular class. Drawing on the conceptual framework for this research, we define such mentors as being involved in second-order work (in that they are inducting student teachers into the profession), but it is important to note that this work takes place within the first-order settings of their schools, drawing on their localised, practitioner knowledge of those settings in order to induct student teachers. 


\section{Methodology}

This research stands within what Silverman (1993) defines as the interpretive tradition of social science, which he sees as concerned with concepts of social construction in meaning. This is a qualitative study that is grounded in the individual's understanding and experiences of their experiences as new teacher educators. The sample group was 28 teacher educators working on ITE courses in seven HEls, including three 'old' universities, three 'new' universities, and one College of Higher Education (CHE).2 In selecting the institutional sample for this study we followed a replication not a sampling logic (see Yin, 1988, p. 53). Replication logic was deemed more appropriate because the number of potential variables when considering different types of HEls was too great to represent in a small empirical study. Furthermore, the aim of the research was not to attempt to establish representative findings for all teacher education institutions, but rather to explore and illustrate the experiences of new teacher educators.

The technique of purposive sampling (see Cohen \& Manion, 1994; Merriam, 1988) was used to select interviewees at each institution. All the individuals in the sample group were in their first 3 years of HE-based ITE work, and had taught in primary or secondary schools at some point in their first careers. Eight individuals were in their first year of HE work and 20 in their second or third years. All were teaching ITE courses, on full-time contracts.

The study drew on data from two sets of in-depth, semi-structured individual interviews, using a schedule of questions developed during the piloting process. All the teacher educators were asked to reflect on their experiences of making the transition from the school sector to HE, identifying and discussing any major areas of tension. The group of teacher educators in their second or third years of HE work were asked to reflect on when or if they felt that being a 'teacher educator' had become part of their professional identity, and what factors had been influential in achieving this. Within this semi-structured format, the interviews were as open as possible, allowing the interviewer to pursue any unexpected responses and to reflect each interviewee's experiences and perceptions of her/his career transition needs.

Questionnaires were used to collect relevant biographical details prior to the interviews, including details of previous careers in the school sector, subject expertise, 
and teaching responsibilities in HE. Analysis of this data enabled aspects of each individual's professional history to be identified.

The data emerging from the interviews and the questionnaires were subjected to content analysis that generated a number of emergent themes through the use of open coding (Strauss, 1987; Strauss \& Corbin, 1990). The resulting codes were refined by repeated analysis and then used to define recurring themes and patterns, resulting in the creation of core categories (Glaser \& Strauss, 1967). This inductive process enabled unexpected elements of the data to be analysed. Emergent categories were used by independent raters to obtain measures of inter-rater reliability. Agreement ranged between $81 \%$ and $92 \%$. Disagreements were resolved by discussion.

\section{Biographical data for the sample group}

Analysis of the biographical data from the questionnaires showed the following patterns: in this study all of the teacher educators were experienced schoolteachers, many with more than 10 years of teaching experience. The data shows that the baseline qualification for entry into ITE work was Masters level, although one interviewee had a Doctorate in a discipline outside education and six had only first degrees plus relevant professional qualifications (usually a Post Graduate Certificate in Education-PGCE-which had given them Qualified Teacher Status) (Table 1).

All teacher educators in this study had experience with mentoring student teachers within their particular school settings, but few stated that they had had opportunities for more extensive mentoring in schools other than their own, or for teaching on a sustained basis in the second-order setting of a university before entering their new occupations. Only one of the sample group had had opportunities for sustained engagement in educational research beyond Masters level (this was one teacherresearcher who had taken part in a university sponsored action research project and had published her work widely). For the rest of the sample group knowledge and understanding of educational research had been developed only through Masters level work or their own ITE courses. For nearly all of these new teacher educators then, opportunities for anticipatory socialisation activities in the second-order setting had been limited prior to their entry to HE. 


\begin{tabular}{|l|l|}
\hline \multicolumn{1}{|c|}{ Category of data analysis } & \multicolumn{1}{c|}{ Number of interviewees $\mathbf{n}=28)$} \\
\hline Entry qualifications & $\begin{array}{l}\text { Doctorates: } 1 \\
\text { Masters degree completed: } 15 \\
\text { Masters degree in process: } 6 \\
\text { First degree + professional qualifications: } 6\end{array}$ \\
\hline Years in school teaching & $\begin{array}{l}4-5 \text { years: } 2 \\
6-10 \text { years: } 10 \\
11-15 \text { years: } 9 \\
15+\text { years: } 7\end{array}$ \\
\hline $\begin{array}{l}\text { Experiences of anticipatory } \\
\text { socialisation (interviewees } \\
\text { defined these from given } \\
\text { categories) }\end{array}$ & $\begin{array}{l}\text { Mentoring student teachers in own } \\
\text { school/classroom contexts: } 28 \\
\text { Mentoring student teachers in contexts beyond } \\
\text { own school: } 7 \\
\text { Sustained teaching in HE: } 3 \\
\text { Sustained research (beyond Masters level): } 1\end{array}$ \\
\hline
\end{tabular}

Table 1 - Analysis of biographical data

\section{Findings from the Interview Data}

The transition from the first-order setting of school teaching into the second-order setting of HE-based teacher education was constructed by the majority of the interviewees as a distinct and stressful career change, characterised by high levels of uncertainty and anxiety. Recurring feelings about the early years of HE work were of being 'de-skilled', of 'struggle', and of 'masquerading'. These feelings were particularly acute during the first year. Learning to become a teacher educator was seen as a slow, uncertain process, requiring the acquisition of new professional knowledge and understanding. Overall, the interviewees identified the following areas of growth and learning during their first 3 years of HE-based teacher education:

- the acquisition of the pedagogical knowledge and experience appropriate to being a teacher educator in $\mathrm{HE}$;

- the enhancement and generalisation of their existing knowledge base of schooling;

- developing an identity as a researcher;

- developing ways of working with mentors in school-based settings;

- acquiring pragmatic knowledge of the HE institution and how it operated. 
From this list, the development of pedagogy for teaching teachers, and the generation of research and scholarship emerged as the key areas of development and these issues are discussed in detail below. The results for the other areas will be mentioned briefly.

All but two of the interviewees found the transition from school to HE-based teacher education to be stressful. The first year was identified as particularly difficult, although half of the interviewees reported that they continued to face challenges in their second and third years of HE work. The experiences of Andrea $^{3}$ describe the sense of bewilderment reported by many of the interviewees in the first year. She said:

The first year? God, tough. How did I feel? Confused, always confused. It was like nothing joined up, as if, well, I felt that nothing was in my control. I kept searching for patterns but there didn't seem to be any, no identifiable routines, not like school where even when times were tough you always knew that the bells would ring to tell you when to start the day, when to stop, when to move classes, and there's some security in that isn't there? Plus my life in school was always busy, surrounded by people but here I was often alone [...] like I couldn't find colleagues when I needed them and I didn't know how to use my free time and that made me feel well very anxious, stressed, uncertain.

For others the experiences of becoming a teacher educator were different, if no less stressful. The process of induction was complex and characterised by the need to come to terms quickly with the demands of their new occupation. Teaching at HE level was a particular focus of anxiety, as Liese describes,

I felt incredibly anxious, exposed, vulnerable and very uncertain about the teaching. I seemed to arrive one minute and then to just plunge headlong into this intensive teaching timetable [in the first year]. I was in a cycle of rapidly revising or updating my own knowledge and then reproducing it-in inverted commas - for these huge groups of students that I felt I was teaching very badly. To be honest I often didn't know why I was here or whether I even should be-me teaching in a university it didn't seem right at all-and along with that there were strong feelings for me of masquerading and being about to be found out for a shameful impostor. I felt de-skilled-it was as if all my years of teaching experience had fallen away and I was left feeling inadequate and exposed in this strange new world.

Themes of 'survival', anxiety about 'fitting in' and striving to make sense of HE work were dominant in the accounts of life in the first year of teacher education work. Despite their school teaching experience, 26 of the interviewees reported feeling 
exposed, vulnerable and uncertain about their new teaching roles in HE. This study shows that for these teacher educators there was no straightforward 'transfer' of the pedagogical knowledge and experience acquired in and through school teaching to the HE context.

All the interviewees emphasised how important it was to develop new pedagogical knowledge of how to teach in HE. As one interviewee stated, reflecting on his own feelings of being de-skilled on entry to HE,

It wasn't that I didn't know the day to day subject stuff, obviously I did, but I knew how to teach it to year 7 [pupils aged 11-12 years] or 10 [pupils aged 1415 years], not how to teach students about how to teach biology to kids-if that makes sense? - it was that sense of-I don't know-remove that made me anxious, knowing that I had to find ways to develop their knowledge of how and what to teach and for that my own knowledge needed to be $150 \%$.

Another interviewee, Sonia, reflected on the length of time it took her to develop her pedagogical knowledge and understanding,

It was like I had to shift the lens of the way I look at teaching. I mean, I've had to shift from thinking about how I taught in school to how my students are learning to teach from me here in this place and that's what I really had to learn in my first year-well no first two years here if I'm honest.

For interviewees in the first year of induction some concerns about teaching were instrumental. For example, of the eight teacher educators interviewed in their first year of HE work seven had concerns such as how to construct and 'deliver' lectures, how to pace and time seminars, and how to manage discussion-based learning. Five interviewees, looking back on their first year, reflected on how they felt their teaching had been transmission orientated. Orla said,

When I look back I think my teaching then could probably be described as giving 'tips for teachers'... I concentrated on giving them (the students) as much of my own knowledge about teaching as I could, oh yes, I certainly gave lots of advice then [...] I suppose that was like a security blanket for me but I so much wanted to give help to them too and I didn't really know how.

In other retrospective accounts of first year teaching experiences, phrases which emphasised transmission orientated teaching methods were common. These included 
interviewees relating, often wryly, 'trying to sell my knowledge', 'trying to graft on all my years of experience on to them' (the students) or 'saying this what worked for me, I'm the expert'.

In the second and third years of HE work interviewees were more likely to express concern about how to develop their teaching skills to enhance student learning. Interviewees talked about needing to learn how to draw on their strong, personal knowledge and understanding of schooling when teaching students. Issues about what to teach (the content of teaching sessions, in effect) were often integrally linked in these accounts with dilemmas about how to teach (the pedagogical modes to be used) and when (judging what were often termed the 'stages' of student teachers' development at which such interventions might be appropriate). Janna, in her third year, said, for example,

I do feel that my teaching has developed a lot but I'm still experimenting with ways of supporting my students in their learning, here at the university and out in schools, you know? I'm still always asking myself what are the best ways of teaching this or that and, most important of all, how do I, how do we all here, help them to put together all these experiences into a coherent whole, create their own visions of what teaching is and should be.

Amidst the uncertainty of their new roles, the majority of the interviewees (26 of 28) reported emphasising their school teaching experience with students, or doing what Liese described as 'clinging to the life raft' of school. This tendency was particularly marked in accounts from the first year interviewees or in retrospective reconstructions of their first year from more experienced interviewees. Firstly, the interviewees related stressing their previous identities as good schoolteachers, and celebrating their years of achievement in schools; secondly, this experiential and contemporaneous knowledge of school teaching was constructed this as central to their credibility as a teacher educator. Twenty-five of the interviewees also reported making regular use of accounts or narratives from their time in school when teaching their ITE students; 'telling stories from the classroom' as Jan called this.

This contemporary knowledge of the school context was seen as enabling them to support and empathise with students, as well as being a key to their credibility. David, a teacher educator in his first year, for example, said: 
I know why I'm here, I'm valued for my up-to-date knowledge of what's happening in schools, and the students know that I'm newly out of school and they value that, that I know what it's like out there for them teaching on School Experience.

Eight of the interviewees talked about needing to extend their knowledge base through the acquisition of a more generalised and scholarly knowledge of education. Andrew, stated, for example,

When I was in school I'd have said that I was bang up to date with all the Literacy initiative barrages we got, but when I came here I had so much extra work to do [...] researching the background to what I was teaching, clarifying my own understanding, making sure I had my story straight [...] getting the overview.

Attitudes to undertaking research during the first years in HE varied greatly. For nine interviewees, all working in 'new' universities or in the CHE, research activity was not a priority, either for their individual career development or, reportedly, for the communal aspirations of their education departments. Conversely, for all the other interviewees engaging in research was seen as important and for all of those working in 'old' universities, research engagement was an imperative, partly because of the probationary requirements set by these institutions. ${ }^{4}$

Nineteen of the teacher educators in the sample group related how they struggled to reconcile their ITE teaching with the processes of research and scholarship. For John, for example, it was a matter of accommodating two very different types of work:

The teacher training work here is all busy, busy, meet that target, write this document, all that kind of stuff, but to research I need to have a free mindtime and space to think more deeply_and I'm really struggling with that.

Karen reiterated this sense of the intensity of ITE work, stressing how much time she and her colleagues spent on preparing for the monitoring and inspection processes which the Teacher Training Agency (TTA) and the Office for Standards in Education (Ofsted) placed on her courses.

We always seem to be responding to some TTA initiative or another, or preparing for yet another Ofsted inspection and everyone knows that that's so 
important, it's top priority here, it has to be done. So you want to ask, 'How do I do this? Where do I find the time to do the research? Let alone to write it up'.

Other new teacher educators questioned their credentials as 'academics' or doubted their own abilities to research and publish at the levels required by their institutions. Joanne, for example, talked of her own insecurities about research and publication, saying:

I've been here for two years now and I still don't see myself as an 'academic'. That's just not a label I like, it's not me. I say that I'm one of the people here who don't 'do' research and I'm not joking. I don't really know what it means to be a researcher in this job.

Her bewilderment about the kind of research in which she should be engaged, and her doubts about her sense of self-identity as an academic were shared by other interviewees $(n=10)$. The construction of research and teaching as distinctive types of work was a recurring theme in the interviews with these teacher educators. There was no clear sense of how research and teaching might be inter-related and symbiotic as activities in academic life. For all of this sub-group, ITE was constructed as a practical and professionally oriented enterprise, centred around teaching students, in contrast to 'research' which carried negative connotations of engagement with a stereotypically academic world, what several interviewees called 'sitting up in the ivory towers'.

Lack of engagement with research put some of the interviewees into positions, which they perceived to be precarious within their institutions. Barbara, working in an 'old' university, stated:

I've got lots of street credibility with the students and with some staff because of my practical knowledge of schools, but I don't have any kind of research record, so to others here l'm just a waste of space, especially when it comes to the Research Assessment Exercise and to my probationary review which l'll probably fail .

In contrast to the many accounts of struggling with research, the two interviewees who came into HE with existing research experience — Lara who had a doctorate in another discipline, and Terri who had undertaken the action research project—both saw few 
challenges in achieving the research targets they had been set during their probationary years. Lara, for example, said

I'm comfortable with the research. I don't have a problem with that, but I know lots of people who do. I suppose because l'd already done so much before I came here, so no, that's not where the learning challenges are for me.

All of the interviewees were involved in designing and 'delivering' their ITE courses in partnership with schools, as required by English legislation on ITE. This included activities such as field visits to monitor and assess student progress on teaching placements (teaching practices) in conjunction with school-based mentors, teaching on mentoring courses (developing school-based mentors, in effect), and writing new course documentation in partnership with school teachers. Guile and Lucas (1999, p. 212) have referred to such activities as undertaking a 'pedagogy of guidance' with the other professionals involved in student placements.

Approximately two-thirds of the interviewees $(n=19)$ reported that they found that they needed to acquire new skills and knowledge in order to engage with this pedagogy of guidance. Even though all of this sub-group had previous experience of being mentors themselves, they found the shift in their position from teacher-mentor working in the school-based setting (what one interviewee referred to as the insider who knows what's what') to the university tutor visiting that setting challenging. Establishing and maintaining professional credibility in the dual roles of newly ex-teacher and teacher educator was an important priority for most of this group. Nadia summed up some of the challenges here as follows,

Finding new inter-personal skills which I didn't know I had. Working out how to balance the voices of the teachers (mentors), the students and me, especially when placements break down. Working with weak students is especially hardlike at Blakedown school (pseudonym) last year where I was struggling to balance the needs of a failing student with what the mentor wanted for their (sic) kids and school. Then at the end of the day being the one who says to that student, 'no, sorry you've failed'. I didn't have to do that kind of thing when I was teaching.

The process of acclimatisation to HEls as workplaces caused considerable tensions for all the educators. Many of the interviewees described having to 'battle', 'fight' or 
'struggle' their ways through the bureaucratic structures of their respective institutions, particularly in their first year. Feelings of disempowerment caused by the size of the institutions, lack of knowledge of how the systems worked and perceived lack of influence were common. The more senior the post held during the school career, the more sense of disempowerment there seemed to be for the new teacher educators. Mike, for example, previously the head teacher of a large primary school, described how he hated 'having no control, no say at all in my department, it's like ... where I used to run things, now I just have to wait and watch'.

Twenty of the interviewees were in their second or third years of ITE work at the time of the interviews. This group was asked to reflect on when or if they felt that being a 'teacher educator' had become part of their professional identity, and what factors had been influential in achieving this. Eighteen felt that they could claim this professional identity, although most stressed that their learning about the work involved was still on going. The time frame for achieving this status varied from 'the beginning of the second year ... once I started to see the same patterns of the courses repeating themselves' (John) to 'the middle of the third year ... when I could lead a seminar without a sense of dread' (Sonia). Two of the interviewees, both towards the end of their third years of HE work, stated that they felt uncomfortable with the label of 'teacher educator'. Lee, for example, stated, 'I'm a teacher still, still a school teacher after all these years, not a lecturer, or a teacher educator, definitely not an academic, just a teacher'.

For those who did see themselves as teacher educators the key indicator of professional socialisation, mentioned by all 18, was confidence and competence in their teaching. Focusing on student learning as indicative of teaching success was a feature of these accounts. Carla, typically, stated that the transition from teacher to teacher educator occurred for her,

When I felt OK about my teaching, when I knew I really was doing the job of developing their (her students') ideas about teaching, and that I was doing that job well, that's when I saw myself as someone who was, well, really teaching teachers.

For other interviewees the transition occurred when their feelings about 'masquerading' in HE receded, often to be replaced by senses of self-worth. As Linda 
stated '(I felt I had become a teacher educator) when I knew that I had something to contribute to my students' learning'.

Only five of the interviewees, all working in 'old' universities, mentioned becoming research active as a further indicator of professional identity as a teacher educator. Kevin, for example, stated that he became a teacher educator when he published his first article on his Masters research, 'that was when I felt real-contributing to my profession, if that doesn't sound too pompous? That's when I said I've made it in this job—I'm there'. But many other interviewees, working in new universities like John, Joanne and Karen quoted above, continued to feel uneasy, uncertain or anxious about their supposed roles as active researchers well into their third years of HE work.

\section{Discussion}

The transition from being a teacher-mentor working with student teachers in a classroom to being a teacher educator based in HE may look like a small shift to casual observers of ITE. This study shows, however, that there was a considerable and often stressful transition time for the interviewees, as they made the change from first-order practitioner in school to second-order practitioner in HE. The majority of teacher educators in this study took between 2 and 3 years to establish professional identities as teachers of teachers. In terms of forming these new identities, this study shows the alignment of the substantial and the situational selves of teacher educators to be a long and sometimes difficult process during those early years of HE work.

The findings of this study confirm earlier research (see, for example, Sinkinson, 1997; Hatt, 1997) in identifying the transition between school teaching and HE in England as stressful for new teacher educators. The findings are significant, particularly in the context of English ITE where recent government pronouncements (see Department for Education and Employment, 1998; Department for Education and Skills, 2002) have de-emphasised key differences between the roles and practices of HE-based teacher educators and school teacher-mentors. In this section of the article we discuss how and why we see the process of professional socialisation following these patterns. Our analysis draws on the conceptual framework of first- and second-order practice, as outlined above. 
On entry into HE the substantial and situational selves of teacher educators can be considered to be aligned in the majority of cases, but alignment is clearly centred around the previous occupation in the first-order setting. Developed over years of experience, this alignment is based around individual and communal understandings of the often tacit practices and discourses of schooling. This study has shown that the first year of HE work is a particularly stressful time. We conclude that this is because the substantial self remains essentially that of a school teacher during this period. An indicator of this is the repeated use by our interviewees of the 'life rafts' of asserting their professional knowledge and experience as school teachers; by centring their credibility as teacher educators around their experiential knowledge of schooling in this way they are proclaiming their first-order professional identities within the HE settings.

Our analysis sees this as creating conflict, in the first year in particular, since the substantial self remains essentially that of a school teacher, whilst their work situation is changing, with new teacher educators being influenced by academic peers and repeated encounters with new and powerful discourses and practices of HE-based ITE work. At this point the substantial and situational selves of the teacher educators are out of alignment, causing feelings of professional unease and discomfort.

Moving into the second and third years, the substantial self continues to change as a result of the new teacher educator's interactions with the HE setting and the practitioners within it. Individual and communal understandings of the often tacit practices and discourses of HE-based ITE are inextricably involved in this aspect of professional socialisation. As new teacher educators continue the process of achieving alignment between their substantial and situational selves in these years, the substantial self is reframed. This reframing occurs in part because the socialisation process is not passive but active, with each educator creating and recreating their personal and communal understandings of their roles as teachers of teachers in HE. The process of achieving alignment is completed at different points over the first 3 years for most individuals, but with a small number of individuals in this study still asserting their first-order identities as school teachers, and rejecting professional identity as an HE-based teacher educator, after almost 3 years in the second-order setting. 
A number of factors are relevant in considering the length of time taken for professional socialisation to occur in this study. Firstly, analysis of the biographical data has shown that most of the interviewees in this study were very experienced schoolteachers, but that few of them had had opportunities for anticipatory socialisation activities prior to assuming their new posts. We argue that this absence of prior relevant experience created additional pressures for most of these teacher educators during the transition period. Secondly, in terms of assuming the role of teachers of teachers we identify that the interviewees were positioned as the expert become novice, in that they needed to acquire new knowledge and understanding of HE teaching, even though they had extensive experience of school teaching. Thirdly, most of these teacher educators came into academic life without sustained experience of research in the field of education, but many were expected to become active researchers within a short period of time. We argue therefore that in terms of research activities they were positioned as the novice assumed to be expert. There was considerable variation in our findings about research engagement, often attributable to differences in institutional expectations. This issue which we relate to a consideration of institutional socialisation is discussed in more detail below.

Fourthly, in the English HE system the effectiveness of current induction arrangements for supporting both pedagogy and research developments have been questioned (see Gilpin, 2003; Murray, 2003; Wilson, 1990). This finding raises questions about how induction support could be revised to support the transition from schooling to HEbased ITE work which we address in the conclusion to this article.

In culmination these factors help to explain both the time taken for the transition from school teacher to teacher educator, and the stresses and challenges experienced within this period as alignment of substantial and situational selves takes place. Of particular significance here is the issue of teacher educators' knowledge and pedagogy, since our findings show that becoming a confident second-order practitioner, as a teacher of teachers, was the key indicator of achieving the new professional identity. 
Earlier in this paper we have argued that teacher educators are second-order practitioners, inducting their students into the professional field of teaching, and that as such the 'subject' or 'discipline' of education and the pedagogical knowledge of how to teach that 'subject' in HE are inseparable for them. Our findings indicate that there was no straightforward transfer of pedagogical knowledge from schooling to $\mathrm{HE}$ to facilitate this process. We assert that this is in part because ITE work demands new and different types of professional knowledge and understanding, including extended pedagogical skills, from those required of schoolteachers (see Koster, Korthagen, \& Wubbels, 1998; Smith, 2003).

Studies of new faculty in disciplines outside teacher education have identified some similar patterns in the challenges involved in becoming an academic, particularly in coming to terms with HE teaching (see, for example, Trowler \& Knight, 2000; Boice, 1992). We argue that whilst there are some clear similarities between the experiences of all new faculty and the teacher educators in our study, there are also some distinct differences, which make teacher educators a particular type of academic. Most new faculty, for example, benefit from induction support in developing their knowledge, understanding and skills as teachers in HE. But unlike teacher educators, few academics come into academic life already established as 'expert teachers', albeit in the school sector. We argue that the need to acquire the new and extended pedagogical skills of teacher education, together with individual and institutional assumptions that new teacher educators already possess pedagogical expertise, creates the unique position of expert become novice for teacher educators as an academic group.

One of the major challenges for the teacher educators in this study was to identify how they could draw on their accumulated professional knowledge and understanding of school teaching to achieve feelings of personal confidence and competence about inducting student teachers into the profession. Equipped with their personal and practical understanding of teaching in first-order settings, these new teacher educators still needed, in the words of Sonia, quoted above, to 'shift the lens' of that existing knowledge to meet the demands of being a second-order practitioner in teacher education. This issue raises questions about what professional knowledge teacher educators need, what pedagogical understanding and skills they require, and about 
how these things differ from the knowledge, skills and understanding of school teachers and teacher mentors.

It is widely argued that teacher educators need an extensive knowledge base of schooling and teacher education (see John, 1996) and engage in extended and complex pedagogical roles in their teaching. The Standards for Dutch teacher educators (see Koster \& Dengerink, 2001; Koster, Korthagen, Wubbels, \& Hoornweg, 2005) identify five groups of inter-related competencies needed for the role of educating teachers; these relate to knowledge and understanding of the subject(s) or area(s) being taught (content competencies), the ability to teach in ways to develop teacher understanding (pedagogical competencies), organisational competencies, group dynamic and communicative competencies, and developmental and personal growth competencies for working with adult learners.

The Dutch pedagogical competencies are split into three areas: design of curricula and learning environments; action, including differentiation to ensure student learning and development, discussing a variety of pedagogical options, and making pedagogical options in personal teaching used transparent to students; and evaluation, including formative and summative assessment of students' academic and vocational skills, and the stimulating of students' reflective abilities. The US standards for teacher educators share the Dutch analysis of the complex nature of teacher educators' work and stress pedagogical roles in modelling professional practices ( ATE, 2002). This emphasis is reiterated in many other analyses (see, for example, Korthagen, 2001; Loughran, 1996; Russell (1995) and Russell (1997)). Other sources also see the teacher educator as the facilitator and model of reflection on practice through personal pedagogy (see, for example, Fish, 1995; LaBoskey, 1994; Loughran, 1996).

It is useful to separate out these different aspects-or competencies-included in teacher educators' knowledge and understanding, if only as an indication of the sophistication of their work. But in reality good teaching cannot be atomised and reduced to a list; rather it is about the inter-twining of many professional and personal factors into a teaching and learning experience, made coherent by the teacher educator. Teaching as a teacher educator involves identifying the inter-relationships 
between what is taught (the 'content') and how (the pedagogical modes used). It requires from the second-order practitioner an overt knowledge of how one teaches and why; it requires a self-consciousness of practice, although this may not always be communicated to students. Teaching in ITE includes considering not only the interpersonal and inter-professional dynamics between students and teacher educator in the university seminar room, but the foundations which those experiences lay down for the students as practitioners in their future classrooms with their future pupils. In short, practising as a teacher educator demands an engagement in teaching about teaching through the medium of personal pedagogy. We assert that it is achieving this double focus, which makes the transition from schoolteacher to teacher educator particularly unique.

The issue of the place of experiential knowledge of schooling for teacher educators requires some further analysis. As we have indicated above, recent and relevant experience of schooling was used as a source of professional credibility by many new teacher educators in their first year, although such usage was not limited to the first year, as interviewees in their second and third years also reported deploying this strategy. In two cases interviewees towards the end of their third year of teacher education work saw their professional credibility and identity as still dependent on their experiences of schooling. Such uses of experiential knowledge to assert credibility are in many ways understandable in that it makes good common sense for new teacher educators to celebrate their expertise and knowledge as schoolteachers. This is a particular factor in English ITE where such practitioner knowledge is likely to have been an important criterion in their recruitment to $\mathrm{HE}$. But a number of points need to be made about the over-use of first-order experiential knowledge in second-order practice. Firstly, if the celebration of experiential knowledge is part of a teaching strategy which essentially involves the educator attempting to 'transmit' personal knowledge of schooling to student teachers, then it is unlikely to lead to long-term learning about what teaching is and can be, for either student or educator. Secondly, if such practices develop only context specific, procedural knowledge for the student then this again emphasises a limited and technical-rational view of teaching, in both first- and second-order settings. Thirdly, there is evidence from previous research that too strong a sense of professional identity as a school teacher can restrict individual development as a teacher educator (see Ducharme \& Agne, 1989; Murray, 2002). 
The key message here is that becoming a teacher of teachers clearly draws on, but cannot be limited to, the knowledge and understanding of schooling accrued through the practice. As this article argues, in order to achieve the dual focus of teaching about teaching, new teacher educators need to develop further pedagogical knowledge and understanding, appropriate for the second-order setting. The change which our interviewees needed to undertake was not about the 'transfer' of their school teaching skills, but about shifting the lens of that teaching to re-analyse their pedagogy in the light of their second-order practice as teacher educators. There are implications here for induction processes which we identify in the conclusion to this article.

As we have shown, the demands for many university academic staff to be research active during their first 2 years of HE work added to the stresses of beginning teacher educators, with most interviewees expressing difficulty in focusing on this aspect of their new role. Entering HE they encountered professional and organisational demands, which established scholarship and research as integral elements of their new professional identity. As we have stated above, we see these new teacher educators positioned as novice assumed to be expert in terms of engaging research activity. Previous research has also indicated that sustained research involvement is problematic for many initial teacher educators ( Murray (1998) and Murray (2002); Nicol, 1997; Sinkinson, 1997). Other commentators have argued that the dual demands of being both a teacher educator in pre-service education programmes, and an active researcher reinforce the sense of teacher education as the impossible job (see, for example, Maguire, 1994). Acker and Feuerverger's (1997) study of Canadian teacher education suggests that a new generation of teacher educators may now be entering $\mathrm{HE}$, with more research-orientated attitudes and skills already established, but the findings reported here suggest that this is not happening in the teacher education departments of most of these English HE institutions.

In our research we found that expectations about levels of research activity for new teacher educators varied widely. These were related to the reported research achievements and aspirations of each education department, in particular to the level of research outputs attained for the Research Assessment Exercise (RAE) of 2001 and to targets for the future RAE to be held in 2007/08. These departmental factors 
are the only aspect of specific differences between $\mathrm{HE}$ institutions that emerged in this study, with this example of organisational socialisation undoubtedly influencing the interviewees' attitudes to research activity as part of their individual professional identity as teacher educators.

We suggest, however, that a number of general factors may be influencing the difficulties with research engagement found in this study. Firstly, because of the valuation placed on experiential knowledge of schooling in English teacher education, many of these tutors entered HE without sustained experience of research and publication. Secondly, their lack of research experience was reported to be overlooked in terms of the induction support provided for them on their journeys towards becoming educational researchers. These two factors meant that these research novices presumed to be experts entering HE often had little coherent support or impetus to facilitate their development.

The third factor which may affect research engagement is an important but pragmatic one. English ITE is still subject to intensive monitoring and regulation by the state, particularly through interventions by the Teacher Training Agency and inspections conducted by Ofsted. It can be argued therefore that the work of the initial teacher educator is intensifying, causing new staff to become wrapped in the cloak of busy practicality' (Day, 1995, p. 365) and decreasing their chances of becoming active and successful researchers.

Most importantly, our findings indicated that some of our interviewees had no clear sense of how research and teaching might be inter-related and symbiotic as activities in academic life. Rather the practical, professional enterprise of ITE was constructed as dichotomous to research engagement which was seen as a stereotypically academic enterprise. These findings echo previous studies of English teacher educators' engagement in research (see Maguire, 1994; Murray (1998) and Murray (2002)). They point to on-going problems in defining the relationship between teaching and research in teacher education, particularly for individuals and education departments intensively involved in ITE work, and without central government funding for sustained research activities. It is imperative that all teacher education work 
addresses the fields of both first and second order, of schooling and of HE. As Taylor (1983, p. 41) identified,

Teacher education is of its very nature Janus-faced. In the one direction it faces classroom and school, with their demands for relevance, practicality, competence, techniques. In the other it faces the university and the world of research, with their stress on scholarship, theoretical fruitfulness and disciplinary rigour.

We assert that it is impossible to meet these imperatives of teacher education fully without a clear sense of the importance of research for the development of knowledge and understanding of practice in both fields. This in turn involves recognising how engagement in research can inform and enrich individual practice as a teacher educator. As we will elaborate on below, this is well illustrated by the increasing number of self-studies by teacher educators.

\section{Conclusion}

This article has identified that the majority of teacher educators in the sample group took between 2 and 3 years to establish professional identities as teachers of teachers. The findings show the process of achieving these identities to be a long and sometimes difficult one during those early years of HE work. Feelings of professional unease and discomfort were particularly acute during the first year of HE work when the substantial and situational selves of the teacher educators were seen as distinctly out of alignment. Becoming a confident second-order practitioner as an HE teacher was the key indicator of achieving the new professional identity. Our analysis shows that, on entry into their HEls, new teacher educators were positioned as the expert become novice in terms of developing new pedagogies for second-order work, but as the novice assumed to be expert in terms of their research activities. Unsurprisingly then, the main learning points were developing a personal pedagogy for teaching teachers and becoming research active. This study raises a number of questions about the induction structures and processes, which would meet these needs.

Recent studies (see Gilpin, 2003; Murray, 2003; Murray, 2004) have shown that induction procedures for teacher educators in England are highly variable. We assert that sustained induction support for teacher educators in interpreting and 
understanding both the HE setting and the particular nature of ITE work is essential. Induction into the field of HE needs to go beyond the informal, ad hoc induction currently on offer to many English teacher educators (Gilpin, 2003). Induction needs to be tailored to the specific needs of the individual, as well as to the contexts of each education department and its mission statements. These ideas imply an individualised induction curriculum rather than the homogeneous, 'one size fits all' model of induction, currently found in many English universities for teacher educators (Gilpin, 2003; Murray, 2003).

Working from the findings of this small scale study, we suggest that effective induction support for teacher educators needs to begin with a process of analysing the knowledge and understanding about teaching in the first order which new teacher educators bring with them into HE. The aim of this process is to make the personal assumptions, beliefs and practices which have made the individual a successful practitioner in schools explicit and open to analysis. Working from previous practice in this way has three advantages: firstly, it helps those new teacher educators, like Andrew quoted above, who may need to develop their epistemic (see Korthagen \& Kessels, 1999) or overview knowledge of schooling (see Furlong, 1996). Secondly, it emphasises the new and extended pedagogy of the second-order work, and provides a potential platform from which to make and evaluate decisions about what to teach, when and how in ITE programmes. Thirdly, and perhaps most importantly, it explicitly grounds the emerging new pedagogy for $\mathrm{HE}$ teaching in previous pedagogical knowledge. Grounding development as a teacher educator in the pedagogical expertise acquired in the school sector validates that practice, acknowledges its fundamental place in individual professional identity, and assists in the interactive processes of bringing substantial and situational selves into alignment. For new teacher educators, particularly those in the first year of HE work, it would also mean explicitly acknowledging the possible conflicts arising between substantial and situational selves during this time.

In developing these new modes of induction for pedagogy in English teacher education, analysis of the Dutch and American standards for teacher education (ATE, 2002; Korthagen, 2001; Korthagen \& Kessels, 1999; Koster et al., 1998; Lunenberg, 2002) offers significant starting points and the powerful traditions of self-study in 
teacher education developed in Australia, the USA and Canada (see, for example, Loughran, 1996; Loughran \& Russell, 1997) offer important ways of integrating personal pedagogy and research into second-order practice.

Self-study may also help new teacher educators to become researchers because a further emergent suggestion from this study is to re-think research induction priorities. Underlying this suggestion is the longer term need to reframe our understanding of research as an integral and symbiotic part of second-order practice as a teacher educator in English ITE. Without such a reframing, some initial teacher educators, like those in our study, may be in danger of being positioned as only 'semi-academics', rather than as professional educators and academics with full and vital roles in vocational education and training within the field of $\mathrm{HE}$.

We suggest that changes in induction practices for research could include a reassessment of the types of induction that would support a novice or reluctant researcher, a re-consideration of the kind of research that is appropriate and useful for new teacher educators as second-order practitioners to conduct, a realistic reappraisal of the research outcomes which can be expected from them, and in-depth discussion across the sector of how research into both first- and second-order settings can inform and develop practices for school teachers and teacher educators.

We have argued that, because of the double focus on teaching and learning in ITE, where teacher educators teach intending teachers about education through the medium of their personal pedagogy, teacher educators are a particular type of academic. But, despite this emphasis, we also acknowledge that there are other groups of professional educators in the university sector who share with teacher educators central roles in the initial education and training of new members of their occupational groups. These groups include academics educating doctors, nurses and social workers. Like teacher educators, these academics have tended to move from one occupational setting to another, exchanging daily work as practitioners in their original occupational setting for work as educators/academics in universities. We would suggest that the findings of this study indicate some areas for future research in exploring the socialisation of these other professional educator groups, and analysing their induction needs. This would be particularly valuable since knowledge 
and understanding of HE-based professional education and of the practices of professional educators is still in the developmental stages (Watson, 2000; Walker, 2001).

\section{Footnotes}

1. Most teacher education in England is still provided in the HE sector, typically in University Departments of Education (UDEs), although some courses are run in separate Colleges of Higher Education with an affiliation to a university.

2. The 'old' universities are also known as 'established' or 'charter' universities. They were granted university status by charter at some point before 1992. The 'new' universities, also known as 'statute' universities, were previously polytechnics. They were granted university status in 1992. Colleges of Higher Education are diversified HE providers outside the university sector, but often stressing their affiliations to it.

3. Pseudonyms have been used throughout this article to ensure the anonymity of the participants.

4. As part of the requirements for passing their 2-year probationary period, most of the interviewees working in 'old' universities had to produce two published articles or other evidence of sustained research and scholarship.

\section{References}

Acker, S. and Feuerverger, G. (1997). Doing Good and Feeling Bad: The Work of Women University Teachers. Cambridge Journal of Education, 26 (3), 401-421.

Association of Teacher Educators (ATE). (2002). Standards for Teacher Educators. Available at: www.edu.departments/coe/ate/standards/TEstandards.htm (Accessed June 2004).

Barnett, B. (2001). The professional induction of beginning principals in Colorado. Paper presented to the annual meeting of the American Educational Research Association: Seattle, USA, March.

Boice, R. (1992). The New Faculty Member. Jossey Bass, San Francisco Cohen, L. and Manion, L. (1994). Research Methods in Education (4th ed). London: Routledge.

Daresh, J. (1995). Alternative Career Formation Perspectives: Lessons for Educational Leadership from Law, Medicine and Training for the Priesthood. Paper presented to the annual meeting of the University Council for Educational Administration, Salt Lake City, USA, October.

Day, C. (1995). Qualitative Research, Professional Development and the Role of Teacher Educators: Fitness for Purpose. British Educational Research Journal, 21 (3), 357-369.

Day, C. \& Bakioglu, A. (1996). 'Development and Disenchantment in the Professional Lives of Headteachers'. In I. Goodison, A. Hargreaves (Eds.), Teachers Professional Lives. London: Falmer Press, 205-227. 
Department for Education and Employment (1998). Teaching: High Status, High Standards. Requirements for Courses of Initial Teacher Training (Circular 4/98). London: DfEE.

Department of Education and Science (1987). Quality in Schools: The Initial Training of Teachers. London: HMSO.

Department for Education and Skills (2002). Learning to Teach: Requirements for Initial Teacher Training Awards. London: HMSO.

Ducharme, E. (1993). The Lives of Teacher Educators. New York: Teachers College Press.

Ducharme, E. and Agne, R. (1989). 'Professors of Education: Uneasy Residents of Academe'. In R. Wisniewski and E. Ducharme (Eds.). The Professors of Teaching. Albany: New York Press, 67-86.

Eraut, M. (1994). Developing Professional Knowledge and Competence. London: Falmer Press.

Fish, D. (1995). Quality Learning for Student Teachers: University Tutors' Educational Practices. London: David Fulton.

Furlong, J. (1996). 'Do Student Teachers Need Higher Education?' In J. Furlong and R. Smith (Eds.). The Role of Higher Education in Initial Teacher Education. London: Kogan Page, 151-165.

Gilpin, A. (2003). 'Teaching about Teaching: The Knowledge Base of Professional Practice in Education'. In J. Murray (Ed.). New Teacher Educators' Needs: Perspectives from Research and Practice. London: Teacher Training Agency, 4-15.

Glaser, B. and Strauss, A. (1967). The Discovery of Grounded Theory. New York: Aldwin.

Greenfield, W. (1977). Administrative Candidacy: A process of New Role Learning Part 2. Journal of Educational Administration, 15 (2), 170-193.

Greenfield, W. (1985). The Moral Socialization of School Administrators: Informal Role Learning Outcomes. Education Administration Quarterly, 21 (4), 99-119.

Grundy, S. and Hatton, E. (1995). Teacher Educators' Ideological Discourses. Journal of Education for Teaching, 21 (1), 7-24.

Guile, B and Lucas, N. (1999). 'Rethinking Initial Teacher Education and Professional Development in Further Education'. In A. Green and N. Lucas (Eds.). Further Education and Lifelong Learning: Realigning the Sector for the Twenty First Century. London: Bedford Way Papers, 203-224.

Hatt, A. (1997). Teacher into Tutor: A Personal Account of the Move from Primary Teaching to Initial Teacher Education. Multicultural Teaching, 19 (2), 43-47. 
Hatton, E. (1997). Teacher Educators and the Production of Bricoleurs: An Ethnographic Study. Qualitative Studies in Education, 10 (2), 237-257.

John, P. (1996). 'The Subject-Method Seminar and the Role of the Teacher Educator'. In J. Furlong and R. Smith (Eds.). The Role of Higher Education in Initial Teacher Training. London: Kogan Page, 119-138.

Korthagen, F. (2000). 'Teacher Educators: From Neglected Group to Spearhead in the Development of Education'. In G. Willems, J. Stakenborg and W. Veugelers (Eds.) Trends in Dutch Teacher Education. Leuven-Apeldoorn: Garant, 35-47.

Korthagen, F. (2001). 'Teacher Education: A Problematic Enterprise'. In F. Korthagen, J. Kessels, B. Koster, B. Lagerwerf and T. Wubbels (Eds.). Linking Practice and Theory: The Pedagogy of Teacher Education. New Jersey: Lawrence Erlbaum Associates, 1-20.

Korthagen, F. and Kessels, J. (1999). Linking Theory and Practice: Changing the Pedagogy of Teacher Education. Educational Researcher, 28 (4), 4-17.

Kremer-Hayon, L. and Zuzovsky, R. (1995). 'Themes, Processes and Trends in the Professional Development of Teacher Educators'. In T. Russell and F. Korthagen (Eds.). Teachers Who Teach Teachers. London: Falmer, 155-171.

Koster, B.and Dengerink, J. (2001). Towards a Professional Standard for Dutch Teacher Educators. European Journal of Teacher Education, 24 (3), 343-354.

Koster, B., Korthagen, F. and Wubbels, T. (1998). Is There Anything Left For Us? Functions of Cooperating Teachers and Teacher Educators. European Journal of Teacher Education, 21 (1), 75-89.

Koster, B., Korthagen, F., Wubbels, T. and Hoornweg, J. (2005).'Roles, Competencies and Training of Teacher Educators: A New Challenge'. In E. Befring (Ed.), Teacher Education for Quality. Oslo: Association of Teacher Education European, 397-411.

LaBoskey, V. (1994). Development of Reflective Practice: A Study of Pre-service Teachers. New York: Teachers College Press.

Lanier, J. and Little, J. (1986). 'Research on Teacher Education'. In M. Wittrock (Ed.) Handbook of Research on Teaching. New York: Macmillan, 527-569.

Loughran, J. (1996). Developing Reflective Practice: Learning About Teaching and Learning through Modelling. London: Falmer.

Loughran, J. and Russell, T. (1997). Teaching about Teaching. London: Falmer Press.

Lunenberg, M. (2002). Designing a Curriculum for Teacher Educators. European Journal of Teacher Education, 25 (2), 263-278 
Maguire, M. (1994). The Job of Educating Teachers. Unpublished Doctoral Thesis, Kings College, University of London, London.

Merriam, S. (1988). Case Study Research in Education: A Qualitative Approach. San Francisco: Jossey-Bass.

Merton, R. (1968). Social Theory and Social Structure (3rd ed.). New York: Free Press.

Murray, J. (1998). Integration or Dichotomy of Teaching and Research? A Case Study of Primary Initial Teacher Educators. Teachers and Teaching, 4 (1), 143-160.

Murray, J. (2002). Between the Chalkface and the Ivory Towers? A Study of the Professionalism of Teacher Educators Working on Primary Initial Teacher Education Courses in the English Education System. Collected Original Resources in Education (CORE), 26 (3), 1-503.

Murray, J. (2003). New Teacher Educators' Needs: Perspectives from Research and Practice. London: Teacher Training Agency.

Murray, J. (2004). Professional Educators in the English University Sector: $A$ Comparison of Teacher Educators' Professional Practices with those of Medical, Social Work and Nurse Educators. London: University Council for the Education of Teachers (UCET).

Nias, J. (1989). 'Teaching and Self'. In M. Holly and C. McLoughlin (Eds.). Perspectives on Teacher Professional Development. London: Falmer Press, 155172.

Nicol, C. (1997). 'Learning to Teach Prospective Teachers to Teach Mathematics: The Struggles of a Beginning Teacher Educator'. In J. Loughran and T. Russell (Eds.) Teaching about Teaching: Purpose, Passion and Pedagogy in Teacher Education. London: Falmer, 95-117.

Parkay, F. and Hall, G. (1992). Becoming a Principal. Boston: Allyn \& Bacon.

Reeves, J., Moos, L. and Forrest, J. (1998). 'The School Leader's View'. In J. Macbeath (Ed.). Effective School Leadership. London: Paul Chapman, 32-59.

Russell, T. (1995). 'Returning to the Physics Classroom to Re-think How One Learns to Teach Physics'. In T. Russell and F. Korthagen (Eds.). Teachers who Teach Teachers. London: Falmer, 95-112.

Russell, T. (1997). 'Teaching Teachers: How I Teach IS the Message'. In J. Loughran and T. Russell (Eds.). Teaching about Teaching. London: Falmer Press, 32-47.

Schein, E. (1988). Organisational Socialisation and the Profession of Management. Sloan Management Review, 12 (4), 53-65.

Silverman, D. (1993). Interpreting Qualitative Data: Methods for Analysing Talk, Text and Interaction. London: Sage Publications. 
Sinkinson, A. (1997). Teachers into Lecturers: An Agenda for Change. Teacher Development, 1 (1), 97-104

Smith, K. (2003). Teacher Educators' Professional Knowledge: How Does it Differ from Teachers' Professional Knowledge? Paper presented to the annual meeting of the American Educational Research Association, Chicago, April.

Southworth, G. (1995). Looking into Primary Headship: A Research Based Interpretation. London: Falmer Press.

Strauss, A. (1987). Qualitative Analysis for Social Scientists. Cambridge: Cambridge University Press, Cambridge.

Strauss, A. and Corbin, J. (1990). Basics of Qualitative Research: Grounded Theory Procedures and Techniques. Newbury Park: SAGE.

Taylor, W. (1968). 'Training the Head'. In B. Allen (Ed.). Headship in the 1970s. London: Blackwell,140 -152.

Taylor, W. (1983). Teacher Education: Achievements, Shortcomings and Perspectives. Paper presented at The John Adams Memorial Lecture, The Institute of Education, London.

Trowler. P. and Knight, P. (2000). Coming to Know in Higher Education: Theorizing Faculty Entry to New Work Contexts. Higher Education Research and Development, 19 (1), 79-96.

Walker, M. (2001). Reconstructing Professionalism in University Teaching. Buckingham: Society for Research into Higher Education and Open University Press.

Watson, D. (2000). 'Lifelong Learning and Professional Higher Education'. In T. Bourner, T. Katz and D. Watson (Eds.). New Directions in Professional Higher Education. Buckingham: Open University Press, 3-10.

Weindling, D. (2000). Stages of Headship: A Longitudinal Study of the Principalship. Paper presented to the annual meeting of the American Educational Research Association, New Orleans, April.

Wilson, A. (1990). Who Trains the Trainers? European Journal of Teacher Education, $13(1), 69-72$.

Yin, R. (1988). Case Study Research, Design and Methods. Newbury Park: SAGE. 